\title{
A new practical synthesis of 3-amino-substituted 5-aminopyrazoles and their tautomerism
}

Felicia Phei Lin Lim, ${ }^{a}$ Khai Ching Tan, ${ }^{a}$ Giuseppe Luna, ${ }^{b}$ Edward R. T. Tiekink, ${ }^{c}$ Anton V. Dolzhenko a,b*

a School of Pharmacy, Monash University Malaysia, Jalan Lagoon Selatan, Bandar Sunway, Selangor Darul Ehsan 47500, Malaysia

${ }^{b}$ School of Pharmacy and Biomedical Sciences, Curtin Health Innovation Research Institute, Faculty of Health Sciences, Curtin University, GPO Box U1987 Perth, Western Australia 6845, Australia

c Research Centre for Crystalline Materials, School of Science and Technology, Sunway University, Bandar Sunway, Selangor Darul Ehsan 47500, Malaysia

\begin{abstract}
It was found that 3-amino-substituted 5-aminopyrazoles could be effectively prepared via hydrolytic decarboxylation of the corresponding 3,5-diaminopyrazole-4-carboxylates 5 under microwave irradiation. The reactions required short time $(4 \mathrm{~min})$ and were successfully reproduced in a larger scale and under conventional heating mimicking the microwave heating pattern. X-ray crystallography identified two different types of tautomers in crystals of related 5-aminopyrazoles with $p$-toluidyl and $p$-anisidyl moieties at the position 3 , respectively.
\end{abstract}




\section{Introduction}

5-Aminopyrazoles have been well recognised as biologically active compounds and efficient building blocks for the construction of fused heterocyclic molecules of high medicinal value. ${ }^{1}$ Recent studies demonstrated an interesting biological profile for 3,5-diaminopyrazole (1) (Fig. 1). ${ }^{2}$ Hoffmann-La Roche patented 5-amino-3-arylaminopyrazoles (e.g. 2) as antiviral agents, particularly useful for the treatment of hepatitis $C$ virus infection. ${ }^{3}$ Some 3 -aminosubstituted 5-aminopyrazoles of general structure $\mathbf{3}$ were also mentioned in patents as building blocks for the construction of bioactive compounds. ${ }^{4}$ Surprisingly, information on the synthesis of such non-symmetrically substituted 3,5-diaminopyrazoles is rather scarce. The methods earlier developed for the preparation of 3-amino-substituted 5aminopyrazoles $\mathbf{3}$ are limited to heterocyclizations of $\mathrm{N}$-substituted cyanoacetimidate esters or amides of cyanothioacetic acid in their reactions with hydrazine. ${ }^{5,6}$ The main drawbacks of these synthetic approaches included relatively difficult accessibility of starting materials and low yields. ${ }^{3,5,6}$

In our program on the synthesis of new purine-like heterocycles ${ }^{7}$ we required 3amino-substituted 5-aminopyrazoles 3 as synthons for further reactions. ${ }^{8}$ That led us to the development of the described here practical method for the synthesis of compounds 3 . Our interest towards prototropic tautomerism in azoles $^{9}$ prompted us to investigate this phenomenon viz. tautomeric preferences in the representative compounds 3 using X-ray crystallography.<smiles>Nc1cc(N)[nH]n1</smiles>

1<smiles>Nc1cc(Nc2cc(Cl)cc(Cl)c2)n[nH]1</smiles>

2<smiles>[R]Nc1cc(N)[nH]n1</smiles>

3

Figure 1. Selected bioactive 3,5-diaminopyrazoles. 


\section{Results and discussion}

\subsection{Synthesis of 3-amino-substituted 5-aminopyrazoles (3)}

For the synthesis of 3-amino-substituted 5-aminopyrazoles $\mathbf{3}$ we decided to employ readily accessible 3-amino-substituted 5-aminopyrazole-4-carboxylates $\mathbf{5}$, which can be conveniently prepared in good yields from 2-cyano-3-methylthioacrylates 4 using the previously described method (Scheme 1). ${ }^{10}$ The hydrolytic decarboxylation of $\mathbf{5}$ was suggested as a potential route to 3-amino-substituted 5-aminopyrazoles $\mathbf{3}$.

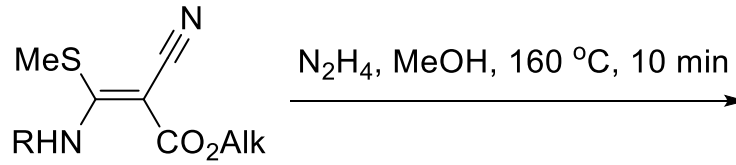

4<smiles>[R]Nc1n[nH]c(N)c1C(=O)O[Na]</smiles>

5

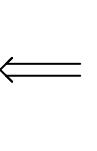<smiles>[R]Nc1cc(N)[nH]n1</smiles>

\section{Scheme 1.}

The initial optimization of reaction conditions for the synthesis $\mathbf{3}$ was performed using ethyl 5-amino-3-phenylaminopyrazole-4-carboxylate (5a) (Table 1). The reaction proceeded under microwave irradiation to form product 3a in $2 \mathrm{~mL}$ of $2 \mathrm{M}$ aqueous solution of $\mathrm{NaOH}$ at $150^{\circ} \mathrm{C}$ for $30 \mathrm{sec}$ (Entry 1). Increasing the time of reaction (Entries 1-6) led to the further improvement of yields with the yield of $81 \%$ achieved at $150{ }^{\circ} \mathrm{C}$ in $4 \min$ (Entry 5). Altering the concentration of $\mathrm{NaOH}$ did not led to an improvement in isolated yields (Entries 7 and 8). Conducting the reaction in $2 \mathrm{M}$ aqueous solution of $\mathrm{K}_{2} \mathrm{CO}_{3}$ or $\mathrm{Na}_{2} \mathrm{CO}_{3}$ led to lower yields (Entries 9 and 10), while changing the base to an acid (Entry 11) resulted in the isolation of the starting material 5 a only.

It should be noted that attempts to carry out the reaction under reflux for $12 \mathrm{~h}$ using $2 \mathrm{M} \mathrm{NaOH}$ solution did not lead to the isolation of $3 \mathrm{a}$ but rather to the recovery of starting material 5a. However, an attempt to carry out the decarboxylation reaction of $\mathbf{5 a}$ in $2 \mathrm{M}$ $\mathrm{NaOH}$, imitating the optimised microwave irradiation conditions in the Monowave 50 reactor (Anton Paar), using sealed vessels under fast conventional heating successfully led 
to the formation of equally pure $\mathbf{3 a}$ in $75 \%$ yield. Therefore, there was minimal (if any) contribution of non-thermal microwave effects in promoting this reaction.

With the optimized conditions in hand, we decided to explore the scope of the reaction with a diverse library of 3-amino-substituted 5-aminopyrazole-4-carboxylates (5) as substrates. Compounds $\mathbf{5}$ were prepared according to the recently developed microwaveassisted approach. ${ }^{10}$ Subsequently, the base-catalysed decarboxylation of ethyl 5aminopyrazole-4-carboxylates $\mathbf{5}$ under microwave irradiation was found to proceed efficiently with the formation of desired products $3 a-3$ il in yields up to $85 \%$ (Table 2). A variety of arylamino and arylalkylamino substituents on the pyrazole ring was well tolerated with exclusive formation of compounds 3, which were isolated in high purity via simple filtration. Using optimized conditions, we also attempted to carry out this reaction with methyl 3,5-diaminopyrazole-4-carboxylates $\mathbf{5}$. For comparison purposes, $\mathbf{3 a}$, $\mathbf{3} \mathbf{h}$ and $\mathbf{3 j}$ were successfully prepared from the corresponding methyl esters 5. In all cases, the hydrolytic decarboxylation of methyl and ethyl esters was efficiently performed in both $0.325 \mathrm{mmol}$ and $3.25 \mathrm{mmol}$ scales with similar outcomes (Table 2).

The structure assignments for the prepared 3,5-diaminopyrazoles 3 were made based on their spectral data. When compared with the spectra of reported staring materials, ${ }^{10}$ we observed the disappearance of the characteristic ${ }^{1} \mathrm{H} N M R$ and ${ }^{13} \mathrm{C} N M R$ signals of the ethoxycarbonyl and methoxycarbonyl groups in addition to the absence of a $\mathrm{C}=\mathrm{O}$ band in the IR spectra. Additionally, a signal assigned to $\mathrm{H}-4$ atom of the pyrazole ring appeared in ${ }^{1} \mathrm{H}$ NMR spectra of 3 at 4.62-5.07 ppm.

Annular prototropic tautomerism is an interesting phenomenon, which has been widely investigated in aminopyrazoles. ${ }^{11}$ In the ${ }^{1} \mathrm{H}$ NMR spectra of the prepared compounds, signals of protons of the exocyclic amino groups, $\mathrm{C}-\mathrm{H}$ proton on the pyrazole ring and

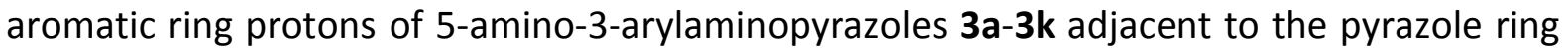
appeared as broad signals. However, the tautomeric transformations were probably too fast to be detected on the ${ }^{1} \mathrm{H}$ NMR time-scale under the experimental conditions and therefore the tautomers were indistinguishable. For the compound $\mathbf{3} \mathbf{l}$, two tautomeric forms $\left(K_{\mathrm{T}}=1.3\right)$ were detected in the NMR spectra in DMSO solution with $1 H$-form of 5 -amino-3phenethylaminopyrazole (3I) being predominant. Further study of the tautomeric preferences was performed on pyrazoles $\mathbf{3} \mathbf{g}$ and $\mathbf{3 i}$ using $\mathbf{X}$-ray crystallography. While to a 
first approximation the molecular structures of $\mathbf{3} \mathbf{g}$ and $\mathbf{3 i}$ appeared to be similar, crucially the compounds crystallized in the form of different tautomers as discussed in detail below.

Table 1. Optimization conditions for the synthesis of 5-amino-3-phenylaminopyrazole (3a) ${ }^{a}$<smiles>CCOC(=O)c1c(Nc2ccccc2)n[nH]c1Nc1ccccc1</smiles>

\begin{tabular}{|c|c|c|c|c|}
\hline Entry & Base/Acid & Temperature $\left({ }^{\circ} \mathrm{C}\right)$ & Time (min) & Isolated yield (\%) \\
\hline 1 & $2 \mathrm{M} \mathrm{NaOH}$ & 150 & 0.5 & 43 \\
\hline 2 & $2 \mathrm{M} \mathrm{NaOH}$ & 150 & 1 & 40 \\
\hline 3 & $2 \mathrm{M} \mathrm{NaOH}$ & 150 & 2 & 76 \\
\hline 4 & $2 \mathrm{M} \mathrm{NaOH}$ & 150 & 3 & 80 \\
\hline 5 & $2 \mathrm{M} \mathrm{NaOH}$ & 150 & 4 & 81 \\
\hline 6 & $2 \mathrm{M} \mathrm{NaOH}$ & 150 & 5 & 72 \\
\hline 7 & $1 \mathrm{M} \mathrm{NaOH}$ & 150 & 4 & 71 \\
\hline 8 & $3 \mathrm{M} \mathrm{NaOH}$ & 150 & 4 & 64 \\
\hline 9 & $2 \mathrm{M} \mathrm{K}_{2} \mathrm{CO}_{3}$ & 150 & 4 & 25 \\
\hline 10 & $2 \mathrm{M} \mathrm{Na}_{2} \mathrm{CO}_{3}$ & 150 & 4 & 30 \\
\hline 11 & $2 \mathrm{M} \mathrm{HCl}$ & 150 & 4 & $0^{b}$ \\
\hline
\end{tabular}

\footnotetext{
a The reaction was performed using a Discover SP CEM microwave synthesizer with 0.325 $\mathrm{mmol}$ of $\mathbf{5 a}$ in $2 \mathrm{~mL}$ of the specified base or acid.

${ }^{\mathrm{b}}$ Only starting material $\mathbf{5 a}$ was isolated.
} 
Table 2. Synthesis of 3-amino-substituted 5-aminopyrazoles (3) from 3,5-diaminopyrazole-4carboxylates (5)

$$
\underset{2 \mathrm{M} \mathrm{NaOH}}{\stackrel{\mu \mathrm{W}, 150^{\circ} \mathrm{C}, 4 \mathrm{~min}}{\longrightarrow}} \mathrm{R}^{1} \mathrm{HN}
$$

\begin{tabular}{|c|c|c|c|c|}
\hline \multirow[b]{2}{*}{ Compound } & \multirow[b]{2}{*}{ Structure } & \multicolumn{2}{|c|}{ Yield (\%) } & \multirow[b]{2}{*}{$\mathrm{Mp}\left({ }^{\circ} \mathrm{C}\right)$} \\
\hline & & $\begin{array}{l}0.325 \mathrm{mmol} \\
\text { scale }\end{array}$ & $\begin{array}{l}3.25 \mathrm{mmol} \\
\text { scale }\end{array}$ & \\
\hline \multirow{2}{*}{$3 a$} & & 81 & 68 & $166-168^{c}$ \\
\hline & & $74^{b}$ & $83^{b}$ & Lit.: 6166 \\
\hline $3 b$ & & 61 & 68 & $165-167^{c}$ \\
\hline $3 c$ & & 60 & 47 & $58-60^{c}$ \\
\hline $3 d$ & & 69 & 57 & $169-171^{d}$ \\
\hline $3 e$ & & 63 & 55 & $138-140^{d}$ \\
\hline $3 f$ & & 42 & 55 & $111-112^{d}$ \\
\hline
\end{tabular}




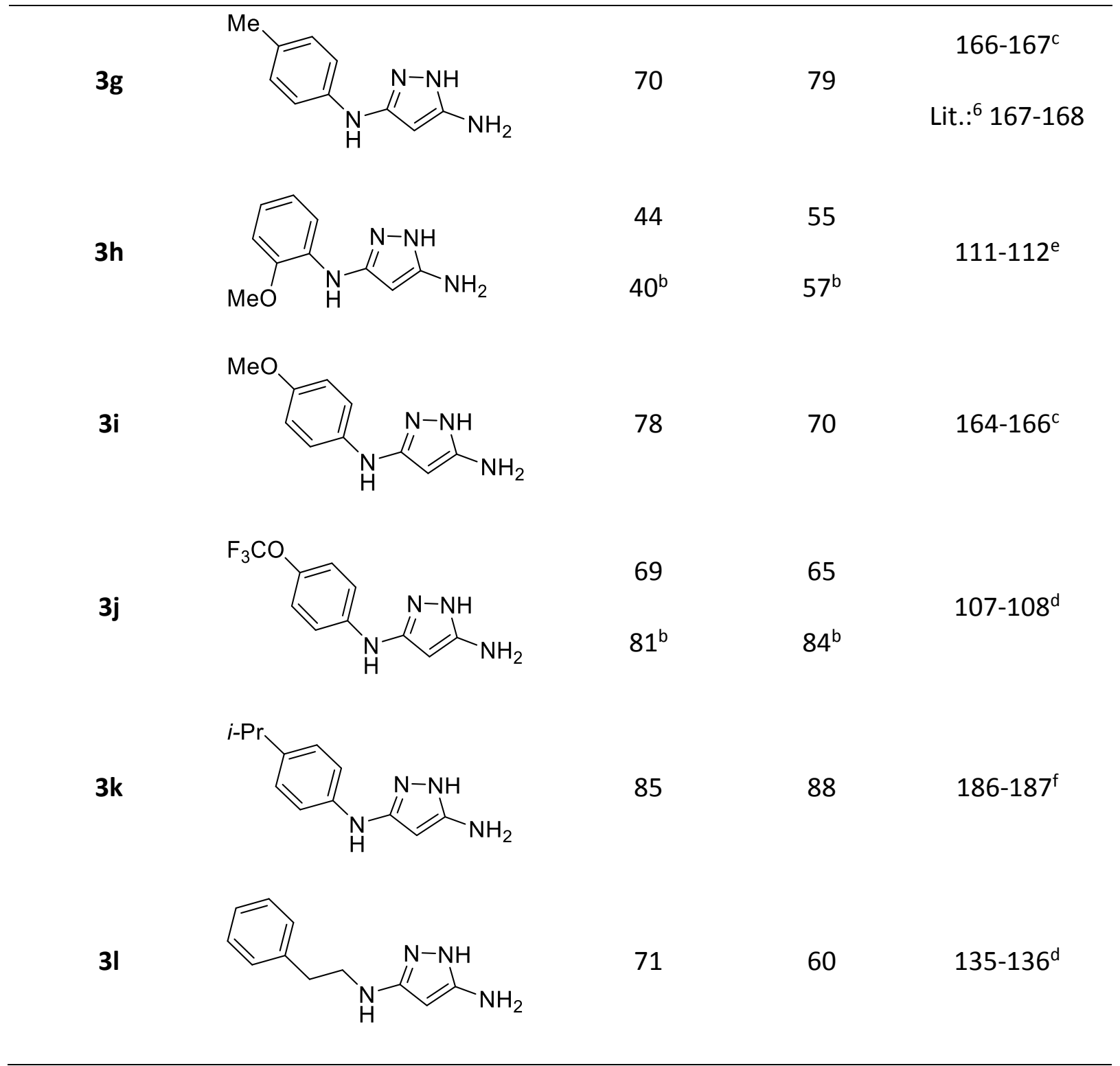

a The reactions were performed using a Discover SP CEM microwave synthesizer with 0.325 $\mathrm{mmol}$ or $3.25 \mathrm{mmol}$ of ethyl 5-aminopyrazole-4-carboxylates $5\left(\mathrm{R}^{2}=\mathrm{Et}\right)$ in $2.0 \mathrm{~mL}$ or $20 \mathrm{~mL}$ of aqueous $2 \mathrm{M} \mathrm{NaOH}$ at $150^{\circ} \mathrm{C}$ for $4 \mathrm{~min}$.

$\mathrm{b}$ The reaction was performed using a Discover SP CEM microwave synthesizer with 0.325 $\mathrm{mmol}$ or $3.25 \mathrm{mmol}$ of methyl 5-aminopyrazole-4-carboxylates $5\left(R^{2}=\mathrm{Me}\right)$ in $2.0 \mathrm{~mL}$ or 20 $\mathrm{mL}$ of aqueous $2 \mathrm{M} \mathrm{NaOH}$ at $150{ }^{\circ} \mathrm{C}$ for $4 \mathrm{~min}$.

Recrystallization solvents: ${ }^{\mathrm{c}} \mathrm{MeOH},{ }^{d} \mathrm{PhMe},{ }^{e} \mathrm{DMF} \& \mathrm{H}_{2} \mathrm{O},{ }^{\mathrm{f}} \mathrm{MeCN}$ 


\subsection{X-ray crystallography of 5-amino-3-arylaminopyrazoles $3 \mathrm{~g}$ and $3 \mathrm{i}$}

The crystallographic asymmetric unit of $\mathbf{3 g}$ comprises two independent molecules, as shown in Figs. 2(a) and (b). The pyrazole ring is planar exhibiting a r.m.s. deviation for the fitted atoms of $0.0021 \AA$ [ $0.0044 \AA$ for the second independent molecule]. The appended primaryN3 and secondary-N5 amine atoms lie 0.073(3) and 0.072(3) A out of and to the same side of the plane through the pyrazole ring $[0.067(3)$ and $0.096(3) \AA]$. Twists in the molecule are noted as seen in the N1-C5-N5-C51 torsion angle of $-155.09(16)\left[-144.91(16)^{\circ}\right]$ and manifested in dihedral angles between the rings of $30.89(8) c f .37 .45(7)^{\circ}$ indicating an inclined relationship, see Fig. 2(c) for an overlay diagram of the two independent molecules.

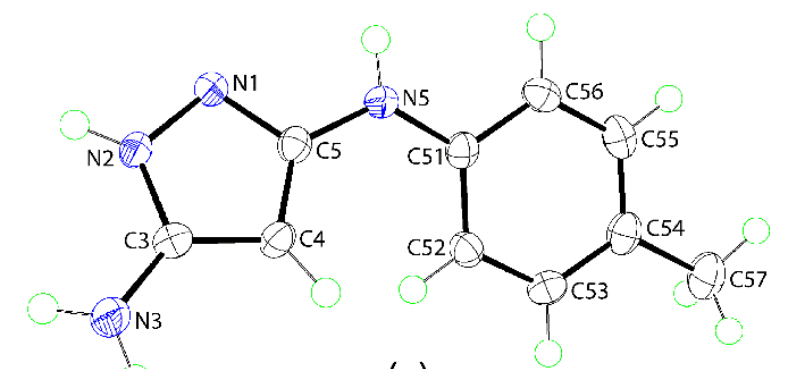

(a)

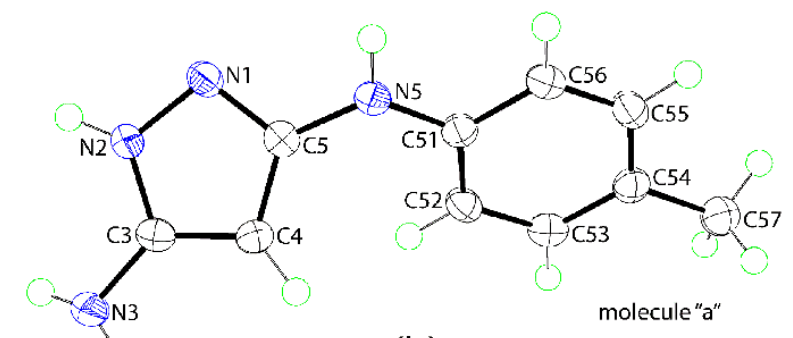

(b)

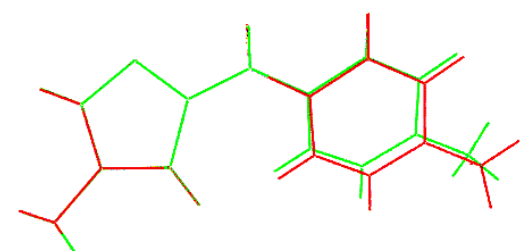

(c)

Figure 2. (a) and (b) The molecular structures of the first and second independent molecules comprising the asymmetric unit of $\mathbf{3 g}$, respectively, showing atom labelling scheme and $\mathbf{7 0 \%}$ anisotropic displacement parameters, and (c) an overlay diagram of the two independent molecules: red image, the molecule shown in (a) and green image, molecule in (b). The molecules are overlapped so that the pyrazole rings are coincident. 
Quite similar molecular features as described for $\mathbf{3 g}$ are also evident in the structure of 3i. Here, four independent molecules comprise the crystallographic asymmetric unit. The first of these is illustrated in Fig. 3(a) and the remainder, i.e. molecules " $a$ ", " $b$ " and " $c$ ", in ESI Fig. $\mathrm{S1}^{\dagger}$. As for $\mathbf{3 g}$, the pyrazole ring is planar [r.m.s. deviations for the fitted atoms of $0.0037,0.0059,0.0040$ and $0.0049 \AA$ for the four independent molecules, respectively]. Differences between the molecules occurs in the relationships between appended primary$\mathrm{N} 3$ and secondary-N5 amine atoms to the pyrazole ring, lying to the opposite sides of the plane for the molecule shown in Fig. 3(a), i.e. 0.131(2) and 0.076(2) $\AA$, and molecule " $b$ " $[0.125(2)$ and $0.074(2) \AA]$, but, to the same side of the plane for molecules "a" [0.178(2) and $0.058(2) \AA]$ and " $c$ " [0.171(2) and 0.056(2) $\AA$ ]. The rings are inclined with respect to each other, forming dihedral angles of 50.22(5), 44.38(5), 50.35(5) and 44.29(5) ${ }^{\circ}$, respectively. Finally, the methoxy group is close to co-planar to the ring it is connected in two molecules while slightly twisted in the other two [C57-O1-C54-C53 torsion angles: -4.0(2), 9.7(2), 4.0(2) and $9.8(2)^{\circ}$, respectively]. The disparity in the dihedral angles between the rings and in the relative orientations of the methoxy groups are highlighted in the overlay diagram of the four independent molecules shown in Fig. 3(b).

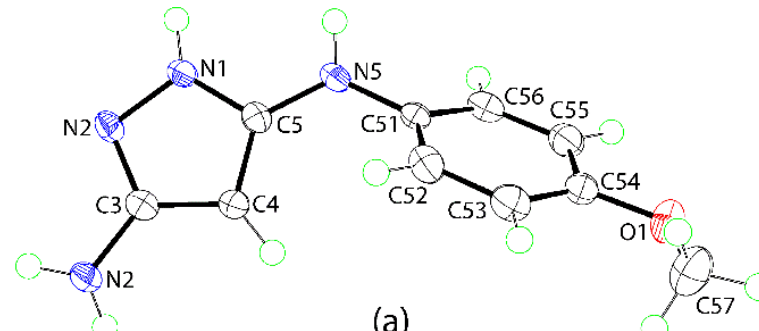

(a)

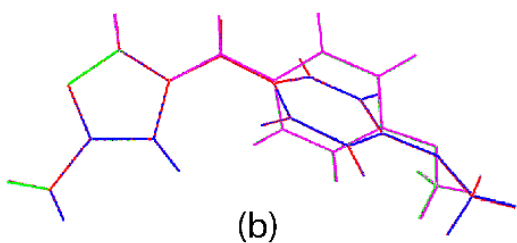

Figure 3. (a) The molecular structure of the first independent molecule of $\mathbf{3} \mathbf{i}$ showing atom labelling scheme and 70\% anisotropic displacement parameters and (b) an overlay diagram of the four independent molecules comprising the asymmetric unit of $\mathbf{3 i}$ : red image, the molecule shown in (c), green image, molecule "a", blue, molecule "b" and pink, molecule " $c$ ". The molecules in are overlapped so that the pyrazole rings are coincident. 
As indicated above, the key differences between the structures of $\mathbf{3} \mathbf{g}$ and $\mathbf{3 i}$ rests in the adopted tautomeric form, with $\mathbf{3 g}$ being in the 3-N-(4-methylphenyl)-1H-pyrazole-3,5diamine form while $3 \mathbf{i}$ is in the 3-N-(4-methoxyphenyl)-2H-pyrazole-3,5-diamine form corresponding to the ring-nitrogen atoms being protonated at the N2 and N1 sites, respectively. As anticipated, the different tautomers give rise to systematic differences in the geometric parameters characterising the ring. Before detailing these, it is noted that only parameters for the molecules shown in Figs. 2(a) and 3(a) are discussed as for each structure, the parameters describing the other molecules comprising the asymmetric units are equal within experimental error to these, respectively. In terms of bond lengths within the rings, the reorganisation of $\pi$-electron density giving rise to the different tautomers results in a decrease [1.345(2) cf. 1.3314(19) $\AA$ ], increase [1.383(2) cf. 1.404(2) $]$ ] and decrease $[1.405(2) c f .1 .389(2) \AA]$ in the N2-C3, C3-C4 and C4-C5 bonds, respectively. In terms of bond angles, the values of the N2-N1-C5 [103.46(13) cf. 111.84(11) $)^{\circ}$ and N1-N2-C3 [111.99(14) cf. $\left.103.70(11)^{\circ}\right]$ follow the trends expected for protonated ring nitrogen atoms. The patterns noted in the molecular packing of $\mathbf{3} \mathbf{g}$ and $\mathbf{3 i}$ also confirm the assignments of the tautomeric forms of the five-membered rings.

The molecular packing of $\mathbf{3 g}$ is replete with $\mathrm{N}-\mathrm{H} \cdots \mathrm{N}$ hydrogen bonding that results in the formation of a supramolecular layer; geometric details of the intermolecular interactions are given in ESI Table $\mathrm{S}^{\dagger}$. Importantly and confirming the assignment of the $1 \mathrm{H}$-pyrazole tautomer, the pyrazole-N2 atom functions as a donor and the adjacent N1 atom behaves as an acceptor for each molecule comprising the asymmetric unit. The independent molecules in $\mathbf{3 g}$ have distinctive hydrogen bonding patterns and there are extensive interactions between the independent molecules. This point is illustrated by the bifurcated hydrogen bonds formed by the pyrazole-N2-H atoms which interact with two pyrazole-N1a atoms of two different (and independent) molecules in contrast to the pyrazole-N2a-H atoms which form hydrogen bonds with each of the pyrazole-N1 and N2 atoms of the same molecule; these pairs of contacts are indicated by " $i$ " and "ii" in Fig. 4(a), respectively. The amine-N3/N3a-H atoms form hydrogen bonds with the pyrazole-N1a/N1 atoms of the other independent molecules and are indicated with "iii" and "iv" in Fig. 4(a). The aforementioned hydrogen bonds serve to link molecules into a helical chain propagating along the $b$-axis. The chains are assembled into a two-dimensional array 
parallel to $\left(\begin{array}{lll}1 & 0 & 1\end{array}\right)$ via interactions involving amine-N3/N3a-H atoms as the donors. The amine-N3-H atoms form hydrogen bonds with the pyrazole-N2a and amine-N3a atoms of different molecules, shown as " $v$ " and " $v i$ ". By contrast, the amine-N3a-H atoms do not form conventional hydrogen bonds with one of these participating in an amine$\mathrm{N} 3 a-H \cdots \pi$ (phenyl) interaction with the first independent molecule, indicated by "vii" in Fig. 4(a) and shown in detail in Fig. 4(b), whereas the second amine-N3a-H atom is separated 2.70 $\AA$ from the amine-N3 atom. Side-on and plan views of the supramolecular layer are shown in Fig. 4(c) and (d). The most obvious contacts between the layers to consolidate the three-dimensional packing are methyl-C57-H $\cdots(\mathrm{C} 51 \mathrm{a}-\mathrm{C} 56 \mathrm{a})$ interactions as highlighted in the unit cell diagram of ESI Fig. $\mathrm{S}^{\dagger}$ from which it can be seen the phenyl groups project to either side of the layer.

Despite there being four independent molecules in the crystal of $\mathbf{3 i}$, to a first approximation the pattern of hydrogen bonding is relatively simple to describe; geometric details of the intermolecular interactions are given in ESI Table $S 2^{\dagger}$. Thus, for each molecule, the pyrazole-N1-H forms a hydrogen bond to a pyrazole-N2 atom (thereby, confirming the $2 \mathrm{H}$-pyrazole tautomer) as does one of the two amine-N3-H atoms so that each pyrazole-N2 accepts two hydrogen bonds. The amine-N5-H atom of each molecule forms a hydrogen bond to the amine-N3 atom. Some variation occurs for the second hydrogen atom of the amine-N3, being linked to amine-N5 in the cases of the molecule illustrated in Fig. 3(a) and molecule " $b$ ". For molecules " $a$ " and " $c$ ", this atom participates in an amine-

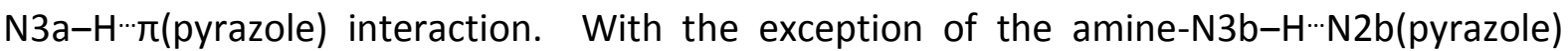
hydrogen bond, all connections occur between different independent molecules. As for $\mathbf{3 g}$, all of the hydrogen bonding in the crystal of $\mathbf{3 i}$ is focussed in specific regions of the crystal and lead to the formation of a supramolecular layers parallel to $\left(\begin{array}{lll}1 & 1 & 0\end{array}\right)$, as illustrated in Fig. 5. The phenyl groups project to either side of the layer and interact via phenyl$\mathrm{C}-\mathrm{H} \cdots \pi$ (phenyl) interactions. Layers stack along the $c$-axis and are separated by hydrophobic interactions; the closest $\mathrm{O} \cdots \mathrm{H}$ contact between layers $(2.88 \AA$ ) is well beyond the sum of their van der Waals radii $\left(2.72 \AA\right.$ ). A view of the unit cell contents is shown in ESI Fig. S3 ${ }^{+}$.

It should be noted that the intermolecular interactions in crystals are critical for the stabilisation of the observed tautomeric forms; therefore, these preferences cannot be directly extrapolated to tautomeric equilibria in solutions. 


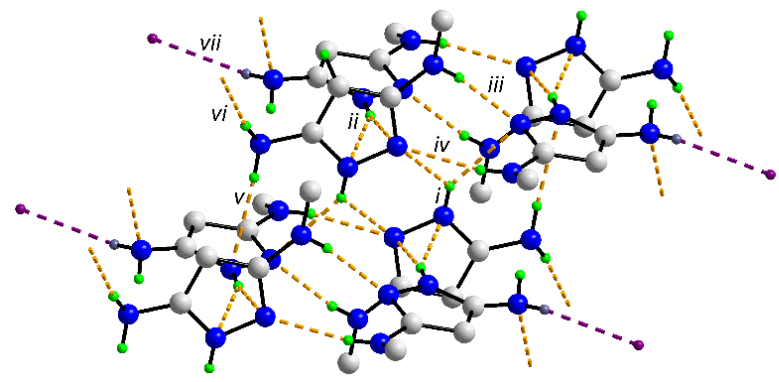

(a)

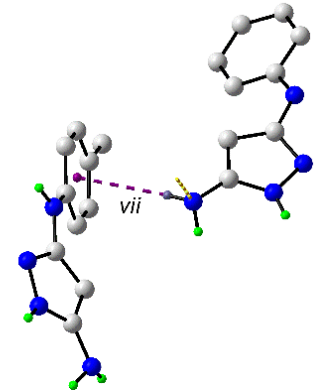

(b)
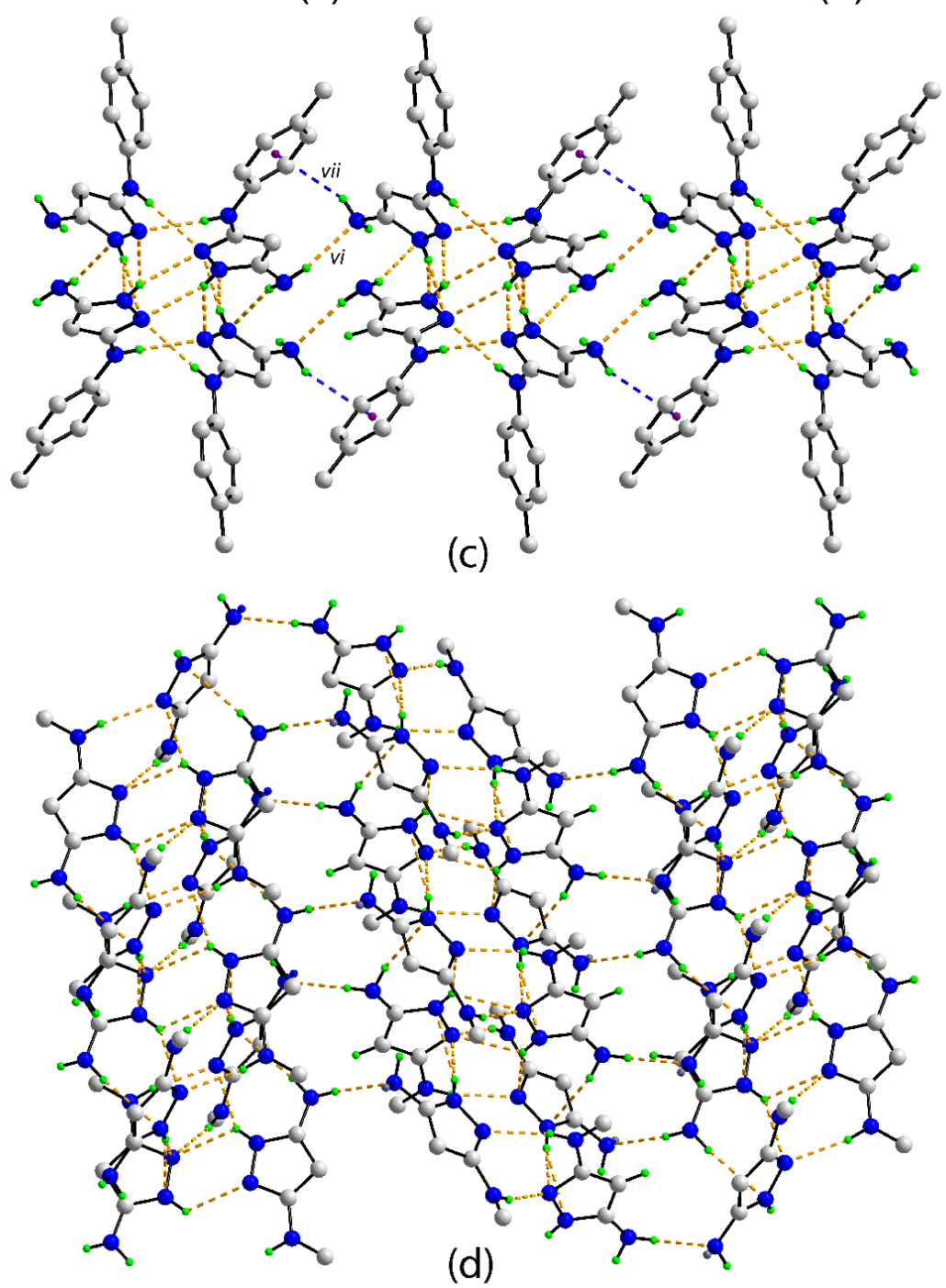

Figure 4. Supramolecular association in the crystal of 3g: (a) $\mathrm{N}-\mathrm{H} \cdots \mathrm{N}$ hydrogen bonding (see ESI Fig. S2 and Table $\mathrm{S}^{\dagger}$ ) leading to a supramolecular chain aligned along the $b$-axis, (b)

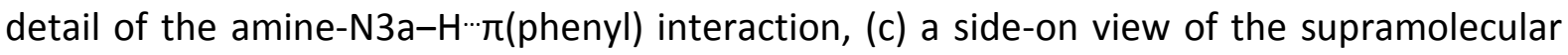
layer parallel to $\left(\begin{array}{llll}1 & 0 & 1\end{array}\right)$ and $(\mathrm{d})$ a plan view of the layer (amine-N3a-H $\cdots \pi($ phenyl) interactions are not shown). Please refer to the text for an explanation of "i"-vii" in (a)-(c). In all 
images, non-participating hydrogen atoms have been removed and in (a) and (d), only the ipso-carbon atom of the phenyl rings are shown.

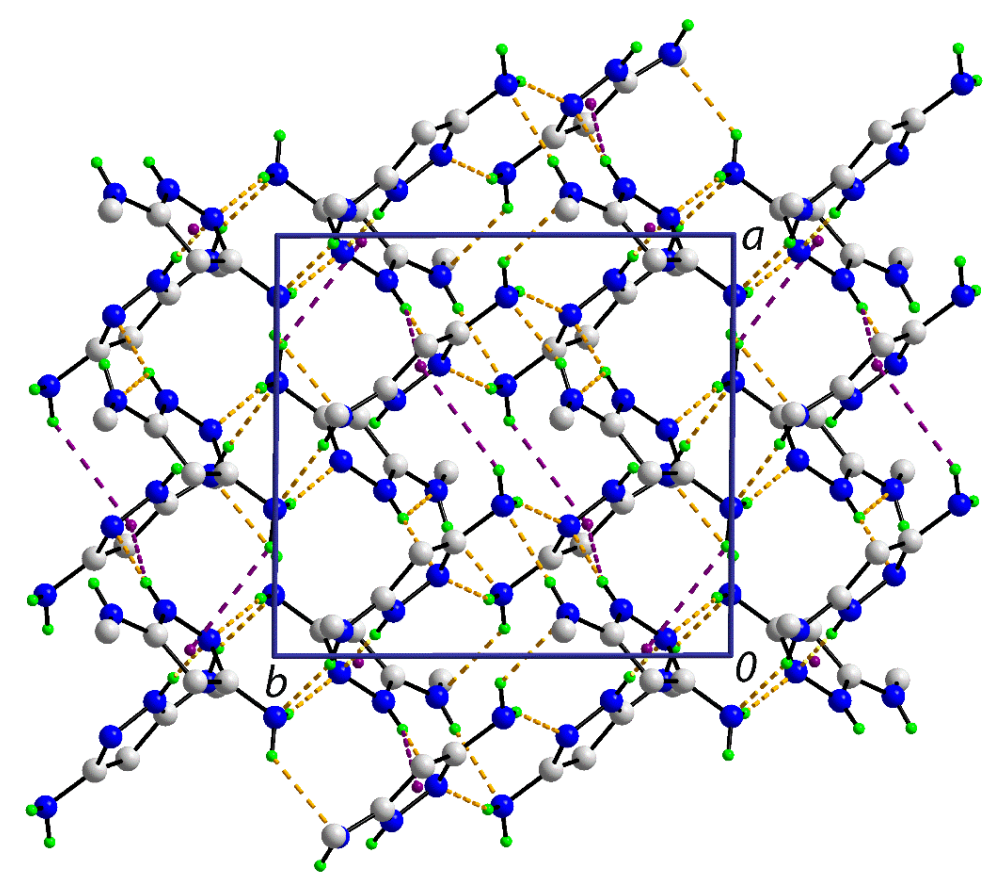

Figure 5. Supramolecular association in the crystal of $\mathbf{3 i}$ : a view of the supramolecular layer parallel to $\left(\begin{array}{lll}1 & 1 & 0\end{array}\right)$. The $\mathrm{N}-\mathrm{H} \cdots \mathrm{N}$ hydrogen bonding and $\mathrm{N}-\mathrm{H} \cdots \pi$ (pyrazole) interactions (see ESI Fig. S3 and Table $\mathrm{S2}^{\dagger}$ ) are shown as orange and blue dashed lines, respectively. Only acidic hydrogen atoms and ipso-carbon atoms of the phenyl groups are shown.

\section{Conclusion}

A new efficient method for the synthesis of 3(5)-amino-substituted 5(3)-aminopyrazoles 3 was developed using hydrolytic decarboxylation of the ester group on the corresponding 3,5-diaminopyrazole-4-carboxylates $\mathbf{5}$ under microwave irradiation. The method was proven to be practical due to operational simplicity, short reaction time, good reproducibility and scalability. The X-ray crystallography performed on two representative aminopyrazoles $\mathbf{3 g}$ and $\mathbf{3 i}$ identified, on the basis of crystallographic refinement, systematic variations of key geometric parameters and intermolecular interactions, the presence of two different tautomers: the $1 \mathrm{H}$ - and $2 \mathrm{H}$-pyrazole, respectively. 


\section{Experimental}

\subsection{General information}

Melting points (uncorrected) were determined on a Stuart ${ }^{\mathrm{TM}}$ SMP40 automatic melting point apparatus. ${ }^{1} \mathrm{H}$ and ${ }^{13} \mathrm{C}$ NMR spectra were recorded on a Bruker Fourier NMR spectrometer (300 MHz) using DMSO- $d_{6}$ as a solvent and TMS as an internal reference. IR spectra were recorded in $\mathrm{KBr}$ pellets using a Varian 640-IR spectrophotometer. Microwave-assisted reactions were carried out in the closed vessel focused single mode using a Discover SP microwave synthesizer (CEM, USA) monitoring reaction temperature by the equipped IR sensor. For the method validation, the model reaction was also carried out using Monowave 400 and Monowave 50 (Anton Paar, Austria) reactors.

4.2 General method for the microwave-assisted synthesis of 3-amino-substituted 5aminopyrazoles 3

An ethyl 3,5-diaminopyrazole-4-carboxylate (5) $(0.325 \mathrm{mmol})$ in $2 \mathrm{M}$ aqueous solution of $\mathrm{NaOH}(2.0 \mathrm{~mL})$ was irradiated in a $10 \mathrm{~mL}$ seamless pressure vial using microwave system operating at maximal microwave power up to $150 \mathrm{~W}$ (Discover SP, CEM) at $150^{\circ} \mathrm{C}$ for $4 \mathrm{~min}$. After cooling, the precipitated product $\mathbf{3}$ was filtered and washed with cold water and recrystallised from a suitable solvent. The reaction was also replicated in an increase scale of ethyl 3,5-diaminopyrazole-4-carboxylates (5) (3.25 mmol) in aqueous $2 \mathrm{M} \mathrm{NaOH} \mathrm{(20} \mathrm{mL).} \mathrm{The}$ same procedure was also effectively applied using the selected methyl 3,5-diaminopyrazole4-carboxylates (5) as the starting material.

\subsubsection{5-Amino-3-phenylaminopyrazole (3a)}

Yield (0.325 / 3.25 mmol scale): 81\% / 68\% (74\% / 76\% from the methyl ester); $\mathrm{mp} 166$ $168^{\circ} \mathrm{C}(\mathrm{MeOH})$, lit.: ${ }^{6} 166^{\circ} \mathrm{C}$; ${ }^{1} \mathrm{H}$ NMR $\left(300 \mathrm{MHz}, \mathrm{DMSO}-d_{6}\right): \delta 4.88-4.91\left(3 \mathrm{H}, \mathrm{br} \mathrm{s}, \mathrm{NH}_{2}\right.$ and H4), $6.63\left(1 \mathrm{H}, \mathrm{t},{ }^{3} \mathrm{~J}=7.1 \mathrm{~Hz}, \mathrm{H}-4^{\prime}\right), 7.11\left(2 \mathrm{H}, \mathrm{t},{ }^{3} \mathrm{~J}=7.8 \mathrm{~Hz}, \mathrm{H}-3^{\prime}\right.$ and $\left.\mathrm{H}-5^{\prime}\right), 7.29\left(2 \mathrm{H}, \mathrm{d},{ }^{3} \mathrm{~J}=6.0\right.$ $\mathrm{Hz}, \mathrm{H}-2^{\prime}$ and $\left.\mathrm{H}^{-} 6^{\prime}\right), 8.01(1 \mathrm{H}, \mathrm{br} \mathrm{s}, \mathrm{NH}), 10.47(1 \mathrm{H}, \mathrm{br} \mathrm{s}, \mathrm{NH}) ;{ }^{13} \mathrm{C}$ NMR (75 MHz, DMSO- $\left.d_{6}\right): \delta$ 77.2 (C-4), 114.7 (C-2' and C-6'), 117.2 (C-4'), 128.5 (C-3' and C-5'), 144.2 (C-1'), 147.9 (C-3), 151.1 (C-5). IR (KBr): v 3359 (N-H), $3310(\mathrm{~N}-\mathrm{H}), 3148$ (C-H), 1618, 1581, 1451, 1276, 1173, 
1093, $1005 \mathrm{~cm}^{-1}$. Anal. calcd. for $\mathrm{C}_{9} \mathrm{H}_{10} \mathrm{~N}_{4}: \mathrm{C}, 62.05 ; \mathrm{H}, 5.8 ; \mathrm{N}, 32.2$. Found: $\mathrm{C}, 61.9 ; \mathrm{H}, 6.0 ; \mathrm{N}$, 31.9.

\subsubsection{5-Amino-3-(4-fluorophenyl)aminopyrazole (3b)}

Yield (0.325 / $3.25 \mathrm{mmol}$ scale): 61\% / 68\%; mp 165-167 ${ }^{\circ} \mathrm{C}(\mathrm{MeOH}) ;{ }^{1} \mathrm{H}$ NMR (300 MHz, DMSO- $\left.d_{6}\right): \delta 4.88\left(3 \mathrm{H}\right.$, br s, $\mathrm{NH}_{2}$ and $\left.\mathrm{H}-4\right), 6.95\left(2 \mathrm{H}, \mathrm{dd},{ }^{3} \mathrm{~J}_{H H}=8.9 \mathrm{~Hz},{ }^{2} J_{H F}=8.9 \mathrm{~Hz}, \mathrm{H}-3^{\prime}\right.$ and $\left.\mathrm{H}-5^{\prime}\right), 7.31\left(2 \mathrm{H}, \mathrm{br} \mathrm{s}, \mathrm{H}-2^{\prime}\right.$ and $\left.\mathrm{H}-6^{\prime}\right), 8.04(1 \mathrm{H}, \mathrm{br} \mathrm{s}, \mathrm{NH}), 10.46(1 \mathrm{H}, \mathrm{br} \mathrm{s}, \mathrm{NH}) ;{ }^{13} \mathrm{C}$ NMR (75 MHz, DMSO- $d_{6}$ ): $\delta 76.7(C-4), 114.7\left(d,{ }^{2} J_{C F}=21.7 \mathrm{~Hz}, \mathrm{C}-3^{\prime}\right.$ and $\left.C-5^{\prime}\right), 115.6\left(\mathrm{~d},{ }^{3} J_{C F}=7.24 \mathrm{~Hz}\right.$, C-2' and C-6'), 140.7 (d, $\left.{ }^{4} J_{C F}=2.2 \mathrm{~Hz}, \mathrm{C}-1^{\prime}\right), 147.9$ (C-3), $151.2(\mathrm{C}-5), 154.7$ (d, ${ }^{1} J_{C F}=233.1 \mathrm{~Hz}$, C-4'). IR (KBr): v 3359 (N-H), $3312(\mathrm{~N}-\mathrm{H}), 3143(\mathrm{C}-\mathrm{H})$, 1624, 1586, 1502, 1278, 1238, 1101, $1005 \mathrm{~cm}^{-1}$. Anal. calcd. for $\mathrm{C}_{9} \mathrm{H}_{9} \mathrm{FN}_{4}$ : C, 56.2; $\mathrm{H}, 4.7 ; \mathrm{N}, 29.15$. Found: $\mathrm{C}, 56.05 ; \mathrm{H}, 4.9 ; \mathrm{N}, 28.0$.

\subsubsection{5-amino-3-(3-chlorophenyl)aminopyrazole (3c)}

Yield (0.325 / $3.25 \mathrm{mmol}$ scale): 60\% / 47\%; mp 58-60 ${ }^{\circ} \mathrm{C}(\mathrm{MeOH}) ;{ }^{1} \mathrm{H}$ NMR (300 MHz, DMSO$\left.d_{6}\right): \delta$ 4.90-4.95 (3H, br s, $\mathrm{NH}_{2}$ and $\left.\mathrm{H}-4\right), 6.64-6.67\left(1 \mathrm{H}, \mathrm{m}, \mathrm{H}-4^{\prime}\right), 7.10-7.15\left(2 \mathrm{H}, \mathrm{m}, \mathrm{H}-5^{\prime}\right.$ and H-6'), $7.62\left(1 \mathrm{H}\right.$, br s, H-2'), $8.36(1 \mathrm{H}, \mathrm{br} \mathrm{s}, \mathrm{NH}), 10.58\left(1 \mathrm{H}\right.$, br s, NH); ${ }^{13} \mathrm{C} \mathrm{NMR}(75 \mathrm{MHz}$, DMSO- $d_{6}$ ): $\delta 77.1$ (C-4), 113.3 (C-6'), 113.8 (C-2'), 116.5 (C-4'), 129.8 (C-5'), 133.1 (C-3'), 145.4 (C-1'), 147.9 (C-3), 150.5 (C-5). IR (KBr): v 3359 (N-H), 3288 (N-H), 3143 (C-H), 1630, $1585,1483,1422,1257,1093,1010 \mathrm{~cm}^{-1}$. Anal. calcd. for $\mathrm{C}_{9} \mathrm{H}_{9} \mathrm{ClN}_{4}: \mathrm{C}, 51.8 ; \mathrm{H}, 4.35 ; \mathrm{N}$, 26.85. Found: C, 51.7; H, 4.5; N, 26.7.

\subsubsection{5-Amino-3-(4-chlorophenyl)aminopyrazole (3d)}

Yield (0.325 / $3.25 \mathrm{mmol}$ scale): 69\% / 57\%; mp 169-171 ${ }^{\circ} \mathrm{C}$ (PhMe); ${ }^{1} \mathrm{H}$ NMR (300 MHz, DMSO- $\left.d_{6}\right): \delta$ 4.89-4.91 (3H, br s, $\mathrm{NH}_{2}$ and $\left.\mathrm{H}-4\right), 7.14\left(2 \mathrm{H}, \mathrm{d},{ }^{3} \mathrm{~J}=8.8 \mathrm{~Hz}, \mathrm{H}-3^{\prime}\right.$ and $\left.\mathrm{H}-5^{\prime}\right), 7.34$ $\left(2 \mathrm{H}, \mathrm{d},{ }^{3} \mathrm{~J}=7.4 \mathrm{~Hz}, \mathrm{H}-2^{\prime}\right.$ and $\left.\mathrm{H}-6^{\prime}\right), 8.24(1 \mathrm{H}, \mathrm{br} \mathrm{s}, \mathrm{NH}), 10.53(1 \mathrm{H}, \mathrm{br} \mathrm{s}, \mathrm{NH}) ;{ }^{13} \mathrm{C}$ NMR $(75 \mathrm{MHz}$, DMSO- $d_{6}$ ): $\delta 77.0$ (C-4), 116.0 (C-2' and C-6'), 120.3 (C-4'), 128.1 (C-3' and C-5'), 142.9 (C-1'), 147.9 (C-3), 150.7 (C-5). IR (KBr): v 3453 (N-H), 3367 (N-H), 3282 (C-H), 1623, 1595, 1548, 1472, 1249, 1177, $1088 \mathrm{~cm}^{-1}$. Anal. calcd. for $\mathrm{C}_{9} \mathrm{H}_{9} \mathrm{ClN}_{4}$ : C, 51.8; $\mathrm{H}, 4.35 ; \mathrm{N}, 26.85$. Found: $\mathrm{C}$, $51.6 ; \mathrm{H}, 4.5 ; \mathrm{N}, 26.6$.

\subsubsection{5-Amino-3-(3-iodophenyl)aminopyrazole (3e)}

Yield (0.325 / $3.25 \mathrm{mmol}$ scale): 63\% / 55\%; mp 138-140 ${ }^{\circ} \mathrm{C}$ (PhMe); ${ }^{1} \mathrm{H}$ NMR (300 MHz, DMSO- $\left.d_{6}\right): \delta 4.89-4.93\left(3 \mathrm{H}, \mathrm{br} s, \mathrm{NH}_{2}\right.$ and $\left.\mathrm{H}-4\right), 6.87-6.92\left(1 \mathrm{H}, \mathrm{m}, \mathrm{H}-5^{\prime}\right), 6.95-6.99(1 \mathrm{H}, \mathrm{m}, \mathrm{H}-$ 
4'), $7.16\left(1 \mathrm{H}, \mathrm{d},{ }^{3} \mathrm{~J}=6.8 \mathrm{~Hz}, \mathrm{H}-6^{\prime}\right), 7.90\left(1 \mathrm{H}, \mathrm{br} \mathrm{s}, \mathrm{H}-2^{\prime}\right), 8.25(1 \mathrm{H}, \mathrm{br} \mathrm{s}, \mathrm{NH}), 10.57(1 \mathrm{H}, \mathrm{br} \mathrm{s}$, $\mathrm{NH}) ;{ }^{13} \mathrm{C}$ NMR (75 MHz, DMSO- $d_{6}$ ): $\delta 77.1$ (C-4), 94.9 (C-3'), 114.1 (C-6'), 122.5 (C-2'), 125.5 (C-4'), 130.4 (C-5'), 145.4 (C-1'), 147.9 (C-3), 150.4 (C-5). IR (KBr): v 3383 (N-H), 3304 (N-H), 3160 (C-H), 1573, 1475, 1395, 1269, 1166, 1095, $1063 \mathrm{~cm}^{-1}$. Anal. calcd. for $\mathrm{C}_{9} \mathrm{H}_{9} \mathrm{IN}_{4}$ : C, 36.0; $H, 3.0 ; N, 18.7$. Found: $C, 35.9 ; H, 3.2 ; N, 18.5$.

\subsubsection{5-Amino-3-(3-methylphenyl)aminopyrazole (3f)}

Yield (0.325 / $3.25 \mathrm{mmol}$ scale): 42\% / 55\%; mp 111-112 ${ }^{\circ} \mathrm{C}$ (PhMe); ${ }^{1} \mathrm{H}$ NMR (300 MHz, DMSO-d $\left.d_{6}\right): \delta 2.20\left(3 \mathrm{H}, \mathrm{s}, \mathrm{CH}_{3}\right), 4.86-4.91\left(3 \mathrm{H}, \mathrm{br} \mathrm{s}, \mathrm{NH}_{2}\right.$ and $\left.\mathrm{H}-4\right), 6.46\left(1 \mathrm{H}, \mathrm{d},{ }^{3} \mathrm{~J}=6.8 \mathrm{~Hz}, \mathrm{H}-\right.$ $\left.4^{\prime}\right)$, 6.96-7.13 (3H, m, H-2', H-5' and H-6'), $7.92(1 \mathrm{H}, \mathrm{br} s, \mathrm{NH}), 10.46(1 \mathrm{H}, \mathrm{br} \mathrm{s}, \mathrm{NH}) ;{ }^{13} \mathrm{C}$ NMR (75 MHz, DMSO-d $d_{6}$ ): $\delta 21.3\left(\mathrm{CH}_{3}\right), 77.2$ (C-4), 111.9 (C-6'), 115.1 (C-2'), 118.1 (C-4'), 128.3 (C5'), 137.3 (C-3'), 144.1 (C-1'), 147.8 (C-3), 151.2 (C-5). IR (KBr): v $3400(\mathrm{~N}-\mathrm{H}), 3302(\mathrm{~N}-\mathrm{H})$, 3235 (C-H), 1581, 1493, 1435, 1282, 1165, 1071, $1000 \mathrm{~cm}^{-1}$. Anal. calcd. for $\mathrm{C}_{10} \mathrm{H}_{12} \mathrm{~N}_{4}$ : C, 63.8; H, 6.4; N, 29.8. Found: C, 63.65; H, 6.6; N, 29.6.

\subsubsection{5-Amino-3-(4-methylphenyl)aminopyrazole (3g)}

Yield (0.325 / $3.25 \mathrm{mmol}$ scale): 70\% / 79\%; mp 166-167 ${ }^{\circ} \mathrm{C}(\mathrm{MeOH})$, lit.: ${ }^{6} 167-168{ }^{\circ} \mathrm{C}$; ${ }^{1} \mathrm{H}$ NMR (300 MHz, DMSO- $\left.d_{6}\right): \delta 2.17\left(3 \mathrm{H}, \mathrm{s}, \mathrm{CH}_{3}\right), 4.86\left(3 \mathrm{H}, \mathrm{br} \mathrm{s}, \mathrm{NH}_{2}\right.$ and H-4), $6.92\left(2 \mathrm{H}, \mathrm{d},{ }^{3} \mathrm{~J}=\right.$ 8.3 Hz, H-3' and H-5'), 7.19 (2H, br s, H-2' and H-6'), 7.86 (1H, br s, NH), $10.41(1 \mathrm{H}$, br s, NH); ${ }^{13} \mathrm{C}$ NMR (75 MHz, DMSO- $\left.d_{6}\right): \delta 20.1\left(\mathrm{CH}_{3}\right), 76.9$ (C-4), 114.7 (C-2' and C-6'), 125.5 (C-4'), 128.8 (C-3' and C-5'), 141.7 (C-1'), 147.8 (C-3), 151.4 (C-5). IR (KBr): v $3399(\mathrm{~N}-\mathrm{H}), 3319(\mathrm{~N}-\mathrm{H})$, 3189 (C-H), 1616, 1580, 1514, 1298, 1180, 1180, $1100 \mathrm{~cm}^{-1}$. Anal. calcd. for $\mathrm{C}_{10} \mathrm{H}_{12} \mathrm{~N}_{4}$ : C, 63.8; H, 6.4; N, 29.8. Found: C, 63.7; H, 6.6; N, 29.6.

\subsubsection{5-Amino-3-(2-methoxyphenyl)aminopyrazole (3h)}

Yield (0.325 / 3.25 mmol scale): 44\% / 55\% (40\% / 57\% from methyl 5-aminopyrazole-4carboxylate); mp 111-112 ${ }^{\circ} \mathrm{C}\left(\mathrm{DMF} \& \mathrm{H}_{2} \mathrm{O}\right) ;{ }^{1} \mathrm{H}$ NMR $\left(300 \mathrm{MHz}, \mathrm{DMSO}-d_{6}\right): \delta 3.82(3 \mathrm{H}, \mathrm{s}$, $\left.\mathrm{OCH}_{3}\right), 4.89\left(2 \mathrm{H}, \mathrm{br} \mathrm{s}, \mathrm{NH}_{2}\right), 5.07(1 \mathrm{H}, \mathrm{br} \mathrm{s}, \mathrm{H}-4), 6.67\left(1 \mathrm{H}, \mathrm{t},{ }^{3} \mathrm{~J}=7.3 \mathrm{~Hz}, \mathrm{H}-5^{\prime}\right), 6.79\left(1 \mathrm{H}, \mathrm{t}, 3^{3} \mathrm{~J}=\right.$ $\left.7.3 \mathrm{~Hz}, \mathrm{H}-4^{\prime}\right), 6.87\left(1 \mathrm{H}, \mathrm{d}, 3^{3} \mathrm{~J}=7.7 \mathrm{~Hz}, \mathrm{H}-3^{\prime}\right), 6.99(1 \mathrm{H}, \mathrm{br} \mathrm{s}, \mathrm{NH}), 7.92\left(1 \mathrm{H}, \mathrm{d},{ }^{3} \mathrm{~J}=7.9 \mathrm{~Hz}, \mathrm{H}-6^{\prime}\right)$, $10.51\left(1 \mathrm{H}\right.$, br s, NH); ${ }^{13} \mathrm{C}$ NMR (75 MHz, DMSO-d $\left.d_{6}\right): \delta 55.4\left(\mathrm{OCH}_{3}\right), 77.7$ (C-4), 109.9 (C-3'), $114.0\left(\mathrm{C}-6^{\prime}\right), 117.4$ (C-4'), $120.6\left(\mathrm{C}-5^{\prime}\right), 132.9\left(\mathrm{C}-1^{\prime}\right), 146.1$ (C-2'), 147.8 (C-3), 150.8 (C-5). IR 
(KBr): v 3423 (N-H), 3339 (N-H), 3310 (C-H), 1600, 1578, 1460, 1296, 1251, 1114, $1023 \mathrm{~cm}^{-1}$. Anal. calcd. for $\mathrm{C}_{10} \mathrm{H}_{12} \mathrm{~N}_{4} \mathrm{O}: \mathrm{C}, 58.8 ; \mathrm{H}, 5.9 ; \mathrm{N}, 27.4$. Found: $\mathrm{C}, 58.7 ; \mathrm{H}, 6.1 ; \mathrm{N}, 27.3$.

\subsubsection{5-Amino-3-(4-methoxyphenyl)aminopyrazole (3i)}

Yield (0.325 / $3.25 \mathrm{mmol}$ scale): 78\% / 70\%; mp 164-166 ${ }^{\circ} \mathrm{C}(\mathrm{MeOH}) ;{ }^{1} \mathrm{H}$ NMR $(300 \mathrm{MHz}$, DMSO- $\left.d_{6}\right): \delta 3.69\left(3 \mathrm{H}, \mathrm{s}, \mathrm{OCH}_{3}\right), 4.85\left(3 \mathrm{H}, \mathrm{br} \mathrm{s}, \mathrm{NH}_{2}\right.$ and $\left.\mathrm{H}-4\right), 6.74\left(2 \mathrm{H}, \mathrm{d}^{3}{ }^{3} \mathrm{~J}=8.8 \mathrm{~Hz}, \mathrm{H}-3^{\prime}\right.$ and $\left.\mathrm{H}-5^{\prime}\right), 7.24\left(2 \mathrm{H}, \mathrm{d},{ }^{3} \mathrm{~J}=7.4 \mathrm{~Hz}, \mathrm{H}-2^{\prime}\right.$ and $\left.\mathrm{H}-6^{\prime}\right), 7.74(1 \mathrm{H}, \mathrm{br} \mathrm{s}, \mathrm{NH}), 10.36(1 \mathrm{H}, \mathrm{br} \mathrm{s}, \mathrm{NH}) ;{ }^{13} \mathrm{C}$ NMR (75 MHz, DMSO-d $\left.d_{6}\right): \delta 55.1\left(\mathrm{OCH}_{3}\right), 76.5$ (C-4), 113.9 (C-3' and C-5'), 115.9 (C-2' and C6'), 138.0 (C-1'), 147.8 (C-3), 151.4 (C-5), 151.7 (C-4'). IR (KBr): v $3395(\mathrm{~N}-\mathrm{H}), 3288(\mathrm{~N}-\mathrm{H})$, 3148 (C-H), 1609, 1583, 1442, 1248, 1178, 1108, $1036 \mathrm{~cm}^{-1}$. Anal. calcd. for $\mathrm{C}_{10} \mathrm{H}_{12} \mathrm{~N}_{4} \mathrm{O}$ : C, 58.8; $H, 5.9 ; N, 27.4$. Found: $C, 58.7 ; H, 6.1 ; N, 27.2$.

\subsubsection{5-Amino-3-(4-trifluoromethoxyphenyl)aminopyrazole (3j)}

Yield (0.325 / $3.25 \mathrm{mmol}$ scale): 69\% / 65\% (81\% / 84\% from methyl 5-aminopyrazole-4carboxylate); mp 107-108 ${ }^{\circ} \mathrm{C}$ (PhMe); ${ }^{1} \mathrm{H}$ NMR (300 MHz, DMSO- $\left.d_{6}\right): \delta 4.91\left(3 \mathrm{H}, \mathrm{br}, \mathrm{NH}_{2}\right.$ and $\mathrm{H}-4), 7.11\left(2 \mathrm{H}, \mathrm{d},{ }^{3} \mathrm{~J}=8.6 \mathrm{~Hz}, \mathrm{H}-3^{\prime}\right.$ and $\left.\mathrm{H}-5^{\prime}\right), 7.38\left(2 \mathrm{H}, \mathrm{d},{ }^{3} \mathrm{~J}=7.1, \mathrm{H}-2^{\prime}\right.$ and $\left.\mathrm{H}-6^{\prime}\right), 8.31(1 \mathrm{H}, \mathrm{br}$ s, NH), 10.55 (1H, br s, NH); ${ }^{13} \mathrm{C}$ NMR (75 MHz, DMSO-d $d_{6}$ ): $\delta 77.0$ (C-4), 115.4 (C-2' and C-6'), $120.3\left(q,{ }^{1} J_{C F}=250.6 \mathrm{~Hz}, C F_{3}\right), 121.5\left(C-3^{\prime}\right.$ and $\left.C-5^{\prime}\right), 139.3\left(q,{ }^{3} J_{C F}=2.5 \mathrm{~Hz}, \mathrm{C}-4^{\prime}\right), 143.4\left(C-1^{\prime}\right)$, 147.9 (C-3), 150.7 (C-5). IR (KBr): v 3400 (N-H), 3295 (N-H), 3209 (C-H), 1583, 1513, 1324, $1219,1175,1003 \mathrm{~cm}^{-1}$. Anal. calcd. for $\mathrm{C}_{10} \mathrm{H}_{9} \mathrm{~F}_{3} \mathrm{~N}_{4} \mathrm{O}: \mathrm{C}, 46.5 ; \mathrm{H}, 3.5 ; \mathrm{N}, 21.7$. Found: $\mathrm{C}, 46.4 ; \mathrm{H}$, 3.6; $\mathrm{N}, 21.6$.

\subsubsection{5-Amino-3-(4-isopropylphenyl)aminopyrazole (3k)}

Yield (0.325 / $3.25 \mathrm{mmol}$ scale): 85\% / 88\%; mp 186-187 ${ }^{\circ} \mathrm{C}(\mathrm{MeCN}) ;{ }^{1} \mathrm{H}$ NMR (300 MHz, DMSO-d 6 ): $\delta 1.15\left(6 \mathrm{H}, \mathrm{d}^{3}{ }^{3} \mathrm{~J}=6.9 \mathrm{~Hz},\left(\mathrm{CH}_{3}\right)_{2}\right), 2.75\left(1 \mathrm{H}, \mathrm{m},{ }^{3} \mathrm{~J}=6.9 \mathrm{~Hz}, \mathrm{CH}\right), 4.85-4.89(3 \mathrm{H}, \mathrm{br}$ s, $\mathrm{NH}_{2}$ and $\left.\mathrm{H}-4\right), 6.99\left(2 \mathrm{H}, \mathrm{d}^{3}{ }^{3} \mathrm{~J}=8.5 \mathrm{~Hz}, \mathrm{H}-3^{\prime}\right.$ and $\left.\mathrm{H}-5^{\prime}\right), 7.17\left(2 \mathrm{H}, \mathrm{d},{ }^{3} \mathrm{~J}=7.4 \mathrm{~Hz}, \mathrm{H}-2^{\prime}\right.$ and $\left.\mathrm{H}-6^{\prime}\right)$, $7.86(1 \mathrm{H}, \mathrm{br} \mathrm{s}, \mathrm{NH}), 10.43(1 \mathrm{H}, \mathrm{br} \mathrm{s}, \mathrm{NH}) ;{ }^{13} \mathrm{C} \mathrm{NMR}\left(75 \mathrm{MHz}, \mathrm{DMSO}-d_{6}\right): \delta 24.1\left(2 \times \mathrm{CH}_{3}\right), 32.49$ (CH), 76.90 (C-4), 114.7 (C-2' and C-6'), 126.1 (C-3' and C-5'), 137.0 (C-4'), 142.0 (C-1'), 147.8 (C-3), 151.4 (C-5). IR (KBr): v 3395 (N-H), 3312 (N-H), 2957 (C-H), 1618, 1597, 1552, 1289, 1187, 1187, $1103 \mathrm{~cm}^{-1}$. Anal. calcd. for $\mathrm{C}_{12} \mathrm{H}_{16} \mathrm{~N}_{4}$ : C, 66.6; $\mathrm{H}, 7.5 ; \mathrm{N}, 25.9$. Found: $\mathrm{C}, 66.5 ; \mathrm{H}$, $7.5 ; \mathrm{N}, 25.8$.

\subsubsection{5-Amino-3-phenethylaminopyrazole (3I)}


Yield (0.325 / $3.25 \mathrm{mmol}$ scale): 71\% / 60\%; mp 135-136 ${ }^{\circ} \mathrm{C}$ (PhMe); ${ }^{1} \mathrm{H}$ NMR (300 MHz, DMSO- $\left.d_{6}\right): \delta 2.77\left(2 \mathrm{H}, \mathrm{t},{ }^{3} \mathrm{~J}=7.4 \mathrm{~Hz}, \mathrm{CH}_{2}\right), 3.14\left(2 \mathrm{H}, \mathrm{q},{ }^{3} \mathrm{~J}=7.0 \mathrm{~Hz}, \mathrm{CH}_{2}\right), 4.15^{*}$ and $4.69(2 \mathrm{H}$, br s, $\left.\mathrm{NH}_{2}\right), 4.62(1 \mathrm{H}, \mathrm{s}, \mathrm{H}-4), 4.69$ and 5.14* $(1 \mathrm{H}, \mathrm{br} \mathrm{s}, \mathrm{NH}), 7.12-7.33(5 \mathrm{H}, \mathrm{m}, \mathrm{Ph}), 10.02(1 \mathrm{H}$, br s, NH); ${ }^{13} \mathrm{C}$ NMR (75 MHz, DMSO-d 6 ): $\delta 35.6\left(\mathrm{CH}_{2}\right), 45.6\left(\mathrm{CH}_{2}\right), 74.7$ (C-4), 125.7 (C-4'), $128.1\left(\mathrm{C}-2^{\prime}\right.$ and $\left.\mathrm{C}-6^{\prime}\right), 128.5$ (C-3' and $\left.\mathrm{C}-5^{\prime}\right), 139.8^{*}$ and $140.3\left(\mathrm{C}-1^{\prime}\right), 148.3$ and 150.0* (C-3), 154.9* and 156.3 (C-5); * - signals of the minor tautomer. IR ( KBr): v $3382(\mathrm{~N}-\mathrm{H}), 3303(\mathrm{~N}-\mathrm{H})$, 3243 (C-H), 1590, 1559, 1499, 1371, 1187, 1099, $1061 \mathrm{~cm}^{-1}$. Anal. calcd. for $\mathrm{C}_{11} \mathrm{H}_{14} \mathrm{~N}_{4}$ : C, 65.3; $H, 7.0 ; N, 27.7$. Found: C, 65.2; H, 7.2; N, 27.45 .

4.3 Synthesis of 5-amino-3-phenylaminopyrazole (3a) via heating in a sealed vessel.

An ethyl 5-amino-3-phenylaminopyrazole-4-carboxylate $(5 \mathrm{a}, 80 \mathrm{mg}, 0.325 \mathrm{mmol})$ in $2 \mathrm{M}$ aqueous solution of $\mathrm{NaOH}(2 \mathrm{~mL})$ was heated in a $10 \mathrm{~mL}$ seamless pressure vial in an enclosed system (Monowave 50, Anton Paar) at $150{ }^{\circ} \mathrm{C}$ for $4 \mathrm{~min}$. After cooling, the precipitate was filtered to obtain a compound, which was identical to 3a prepared under microwave irradiation. Yield 75\%.

\subsection{X-ray crystallographic analysis}

Intensity data for $\mathbf{3 g}$ and $\mathbf{3 i}$ were measured for colourless crystals ( $\mathbf{g} \mathbf{g}: 0.03 \times 0.12 \times 0.23$ $\mathrm{mm}$; 3i: $0.04 \times 0.11 \times 0.21 \mathrm{~mm}$ ) at $100 \mathrm{~K}$ on an Rigaku/Oxford Diffraction XtaLAB Synergy diffractometer (Dualflex, AtlasS2) fitted with CuK $\alpha$ radiation $\left(\lambda=1.54178 \AA\right.$ ) so that $\theta_{\max }=$ 67. $1^{\circ}$. Data reduction and Gaussian absorption corrections were by standard methods. ${ }^{12}$ The structures were solved by direct methods ${ }^{13}$ and refined ${ }^{14}$ on $F^{2}$ with anisotropic displacement parameters and $\mathrm{C}$-bound $\mathrm{H}$ atoms included in the riding model approximation. The $\mathrm{N}$-bound $\mathrm{H}$ atoms were refined freely. A weighting scheme of the form $\mathrm{w}=1 /\left[\sigma^{2}\left(F_{\mathrm{o}}{ }^{2}\right)+\right.$ $\left.(a P)^{2}+b P\right]$ where $\left.P=\left(F_{o}^{2}+2 F_{c}^{2}\right) / 3\right)$ was introduced in each case. In the refinement of $\mathbf{3 g}$, two reflections, i.e. $\left(\begin{array}{lll}2 & 0 & 4\end{array}\right)$ and $\left(\begin{array}{lll}3 & 0 & 1\end{array}\right)$, were removed from the final cycles of refinement owing to poor agreement. The molecular structure diagrams showing $70 \%$ probability displacement ellipsoids were generated by ORTEP for Windows ${ }^{15}$ and the packing diagrams with DIAMOND. ${ }^{16}$ Additional data analysis was made with PLATON. ${ }^{17}$ 
4.4.1 Crystal data for $3 g$ : $\mathrm{C}_{10} \mathrm{H}_{12} \mathrm{~N}_{4}, M=188.24$, monoclinic, $P 2_{1} / n, a=18.0137(5), b=$ 6.15230(10), $c=18.2375(5) \AA, \beta=114.056(3)^{\circ}, V=1845.64(9) \AA^{3}, Z=8, D_{x}=1.355 \mathrm{~g} \mathrm{~cm}^{-3}$, $F(000)=800, \mu=0.693 \mathrm{~mm}^{-1}$, no. reflns meas. $=23354$, no. unique reflns $=3290\left(R_{\text {int }}=\right.$ 0.047 ), no. reflns with $I \geq 2 \sigma(I)=2949$, no. parameters $=287, R$ (obs. data) $=0.045, a$ and $b$ in weighting scheme $=0.047$ and $1.490, w R 2$ (all data) $=0.111$. CCDC deposition number: 1866662.

4.4.2 Crystal data for 3i: $\mathrm{C}_{10} \mathrm{H}_{12} \mathrm{~N}_{4} \mathrm{O}, M=204.24$, triclinic, $P \overline{1}, a=9.6175(2), b=10.4055(2), c$ $=20.1541(3) \AA, \alpha=85.3860(10), \beta=83.139(2), \gamma=89.982(2)^{\circ}, V=1995.90(6) \AA^{3}, Z=8, D_{x}=$ $1.359 \mathrm{~g} \mathrm{~cm}^{-3}, F(000)=864, \mu=0.763 \mathrm{~mm}^{-1}$, no. reflns meas. $=46475$, no. unique reflns $=$ $7127\left(R_{\text {int }}=0.042\right)$, no. reflns with $I \geq 2 \sigma(I)=6104$, no. parameters $=609, R$ (obs. data $)=$ $0.046, a$ and $b$ in weighting scheme $=0.095$ and $0.536, w R 2$ (all data) $=0.139$. CCDC deposition number: 1866664.

\section{Acknowledgements}

The Research Centre for Crystalline Materials (Sunway University) is thanked for the X-ray intensity data. This work is supported by the Ministry of Higher Education, Malaysia under Fundamental Research Grant Scheme, grant number FRGS/1/2015/SG01/MUSM/03/1.

\section{Appendix A. Supplementary data}

+ Supplementary data associated with this article can be found in the online version, at https://doi.org/10.1016/j.tet.XXXX.XX.XXXX

\section{References}

1. For the recent review see: Shaabani, A.; Nazeri, M.T; Afshari, R. 5-Amino-pyrazoles: potent reagents in organic and medicinal synthesis. Mol. Divers. 2019, https://doi.org/10.1007/s11030-018-9902-8.

2. Ben Ali, R.; Ben Othman, A.; Bokri, K.; Maghraoui, S.; Hajri, A.; Ben Akacha, A.; Dziri, C.; El May, M. V., Synthesis and evaluation of analgesic, behavioral effects and chronic toxicity of the new 3,5-diaminopyrazole and its precursor the thiocyanoacetamide. Biomed. Pharmacother. 2017, 86, 109-117. 
3. (a) Plancher, J.-M.; Weikert, R. J. N-Heteroaryl substituted aniline derivatives as HCVantivirals. U.S. Patent 20160000763, 2016; Chem. Abstr. 167, 406598; (b) Plancher, J.-M.; Weikert, R. J. N-Heteroaryl-aniline derivatives as antivirals and their preparation and use in the treatment of HCV infection. WO Patent 2014135423, 2014; Chem. Abstr. 161, 459963.

4. (a) Schiemann, K.; Hoelzemann, G.; Rautenberg, W. Preparation of triazolo[1,5a]pyrimidines and related compounds as TIE-2 kinase inhibitors. WO Patent 2005054246, 2005; Chem. Abstr. 143, 60006; (b) Hunt, P.; Porter, D.; Press, N. J.; Spanka, C.; Watson, S. J. Preparation of (arylsulfanylmethyl)pyrazolo[1,5-a]pyrimidinol derivatives as CXCR2 antagonists. WO Patent 2008062026, 2008; Chem. Abstr. 148, 585919.

5. Sato, T. Preparation of 5-amino-3-arylamino- $1 \mathrm{H}$-pyrazole and $\mathrm{N}$-arylcyanoacetimidate esters. Japan Patent 01283275, 1989; Chem. Abstr. 113, 23907.

6. Grabenko, A. D.; Kulaeva, L. N.; Pel'kis, P. S. Substituted arylamides of dithiocarboxylic acids. IX. Cyclization of arylamides of cyanothioacetic acid to pyrazole derivatives. Khim. Geterotsikl. Soedin. 1967, (4), 713-715.

7. (a) Lim, F. P. L.; Halcovitch, N. R.; Tiekink, E. R. T.; Dolzhenko, A. V., A new microwaveassisted, three-component reaction of 5-aminopyrazole-4-carboxylates: Selective synthesis of substituted 5-aza-9-deaza-adenines. Tetrahedron 2018, 74 (15), 1868-1879; (b) Lim, F. P. L.; Tan, L. Y.; Tiekink, E. R. T.; Dolzhenko, A. V. A one-pot, multicomponent reaction for the synthesis of novel 2-alkyl substituted 4-aminoimidazo[1,2-a][1,3,5]triazines. $R S C A d v ., 2018$, 8(38), 21495-21504; (c) Lim, F. P. L.; Low, S. T.; Ho, E. L. K.; Halcovitch, N. R.; Tiekink, E. R. T.; Dolzhenko, A. V. A multicomponent reaction of 2-aminoimidazoles: Microwave-assisted synthesis of novel 5-aza-7-deaza-adenines. RSC Adv., 2017, 7, 51062-51068; (d) Lim, F. P. L.; Kow, K. K.; Yeo, E. H.; Chow, S. C.; Dolzhenko, A. V. Synthesis and antileukemic activity of new fluorinated 5-aza-9-deazapurines. Heterocycles, 2016, 92 (6), 1121-1131. (e) Lim, F. P. L.; Luna, G.; Dolzhenko, A. V., A one-pot, three-component aminotriazine annulation onto 5aminopyrazole-4-carbonitriles under microwave irradiation. Tetrahedron Lett. 2015, 56 (3), 521-524; (f) Lim, F. P. L.; Luna, G.; Dolzhenko, A. V., A one-pot, three-component, microwave-assisted synthesis of novel 7-amino-substituted 4-aminopyrazolo[1,5a][1,3,5]triazine-8-carbonitriles. Tetrahedron Lett. 2015, 56 (50), 7016-7019; (g) Lim, F. P. L.; Luna, G.; Dolzhenko, A. V., A new, one-pot, multicomponent synthesis of 5-aza-9-deaza- 
adenines under microwave irradiation. Tetrahedron Lett. 2014, 55 (37), 5159-5163; (h) Lim, F. P. L.; Dolzhenko, A. V. 4-Amino-substituted pyrazolo[1,5-a][1,3,5]triazin-2-amines: a new practical synthesis and biological activity. Tetrahedron Lett. 2014, 55(49), 6684-6688; (i) Lim, F. P. L.; Dolzhenko, A. V., 1,3,5-Triazine-based analogues of purine: From isosteres to privileged scaffolds in medicinal chemistry. Eur. J. Med. Chem. 2014, 85, 371-390; (j) Kalinina, S. A.; Kalinin, D. V.; Dolzhenko, A. V. A one-pot, three-component, microwavepromoted synthesis of 2-amino-substituted 7-amino-1,2,4-triazolo[1,5-a][1,3,5]triazines. Tetrahedron Lett., 2013, 54(40), 5537-5540; (k) Kalinin, D. V.; Kalinina, S. A.; Dolzhenko, A. V. A new synthesis of amino substituted azolo[1,3,5]triazines via reaction of $N^{1}, N^{1}$-dimethyl$N^{2}$-azolylformamidines with cyanamide. Heterocycles, 2013, 87(1), 147-154; (I) Dolzhenko, A. V.; Kalinina, S. A.; Kalinin, D. V. A novel multicomponent microwave-assisted synthesis of 5-aza-adenines. RSC Adv., 2013, 3(10), 15850-15855.

8. See the proceeding paper in this issue: Lim, F. P. L.; Luna, G.; Tiekink, E. R. T.; Dolzhenko, A. V., A synthesis of new 7-amino-substituted 4-aminopyrazolo[1,5- $a][1,3,5]$ triazines via a selective three-component triazine ring annulation. Tetrahedron 2019, 75(15), 2322-2329.

9. (a) Lim, F. P. L.; Hu, L. M.; Tiekink, E. R. T.; Dolzhenko, A. V. One-pot, microwave-assisted synthesis of polymethylene-bridged bis(1H-1,2,4-triazol-5(3)-amines) and their tautomerism. Tetrahedron Lett., 2018, 59, 3792-3796; (b) Lim, F. P. L.; Tan, L. Y.; Tiekink, E. R. T.; Dolzhenko, A. V. Synthesis of 3-(5-amino-1H-1,2,4-triazol-3-yl)propanamides and their tautomerism. RSC Adv., 2018, 8(40), 22351-22360; (c) Dolzhenko, A. V.; Pastorin, G.; Dolzhenko, A. V.; Chui, W. K. An aqueous medium synthesis and tautomerism study of 3(5)amino-1,2,4-triazoles. Tetrahedron Lett., 2009, 50(18), 2124-2128.

10. Lim, F. P. L.; Gan, R. X. Y.; Dolzhenko, A. V., Highly selective and efficient synthesis of 3arylamino-substituted 5-aminopyrazole-4-carboxylates under microwave irradiation. Tetrahedron Lett. 2017, 58 (8), 775-778.

11. (a) Oziminski, W. P., The kinetics of water-assisted tautomeric 1,2-proton transfer in azoles: a computational approach. Struct. Chem. 2016, 27 (6), 1845-1854; (b) Nieto, C. I.; Cabildo, M. P.; Cornago, M. P.; Sanz, D.; Claramunt, R. M.; Alkorta, I.; Elguero, J.; Garcia, J. A.; Lopez, A.; Acuna-Castroviejo, D., Synthesis, structure and biological activity of 3(5)trifluoromethyl-1H-pyrazoles derived from hemicurcuminoids. J. Mol. Struct. 2015, 1100, 
518-529; (c) Provasi, P.; Jimeno, M. L.; Alkorta, I.; Reviriego, F.; Elguero, J.; Jokisaari, J., The ${ }^{1} \mathrm{H}$ NMR spectrum of pyrazole in a nematic phase. Magn. Reson. Chem. 2016, 54 (8), 637640.

12. Rigaku Oxford Diffraction, CrysAlis PRO, Yarnton, Oxfordshire, England (2017).

13. Sheldrick, G. M., Acta Crystallogr., Sect. A: Found. Crystallogr., 2008, 64, 112-122.

14. Farrugia, L. J., J. Appl. Crystallogr., 2012, 45, 849-854.

15. Sheldrick, G. M., Acta Crystallogr., Sect. C: Struct. Chem., 2015, 71, 3-8.

16. Brandenburg, K., DIAMOND, Crystal Impact GbR, Bonn, Germany, 2006.

17. Spek, A. L., Acta Crystallogr. Sect. D: Biol. Crystallogr., 2009, 65, 148-155. 